\title{
Methodology of a phonetic experimental research of English video presentations prosody
}

\author{
N. Ya. Hrad \\ Kyiv National Linguistic University, Kyiv, Ukraine \\ Corresponding author. E-mail: natalyhrad@gmail.com
}

Paper received 10.09.20; Accepted for publication 24.09.20.

\begin{abstract}
https://doi.org/10.31174/SEND-Ph2020-235VIII70-03
\end{abstract}
\begin{abstract}
The article focuses on the methodology of the phonetic experimental research of the prosodic means used for the pragmatic influence realization in English video presentations. The paper describes the succession of the experiment stages, the tasks for the auditors-informants and auditors-phoneticians, as well as the prosodic parameters investigated within the auditory and acoustic analysis. Linguistic interpretation and generalization of the results of experimental phonetic research proves that the acoustic analysis data obtained with the help of digital tools of speech analysis correlate closely with the results of the auditory analysis.
\end{abstract}

Keywords: auditory analysis, acoustic analysis, intonation, prosodic means, English video presentation, video-verbal text.

Introduction. Modern linguistic studies are aimed to study speech and its units within the cognitive-discursive and functional-energetic approaches, taking into account the influence of pragmatic factors on their prosodic organization. A detailed study of the phonetic systems interaction and relationships, the semantics and pragmatics of the meaning implementation of media texts, including videoverbal texts, is relevant as it allows to clarify the principles and methods of optimal influence on the recipient. Therefore, there is a need for a comprehensive experimental phonetic research devoted to the study of prosodic means of the English-language video presentations as a kind of video-verbal text.

Review of publications. In recent years, the analysis of functioning of video-verbal (creolized, visually dependent) texts as a linguovisual phenomenon is getting more and more popular among Ukrainian and foreign linguists $[2 ; 4$; $5 ; 7 ; 14]$. Video-verbal texts being a complex multidimensional phenomenon are defined within the framework of cognitive-and-discursive, communicative-and-pragmatic approaches as well as a new energetic approach to the research of speech phenomena [3].

Video-verbal text is defined as a text that has all the characteristics of a coherent text based on the interaction of visual and linguistic aspects [6]. This definition is based on the analysis and generalization of theoretical views and approaches to the interpretation of the concept of a videoverbal text that are available in modern linguistics. At the end of the XX - beginning of the XXI century the intensive elaboration of the typology of texts allowed polycode texts (creolized, video-verbal) to become the object of separate research as a linguo-visual phenomenon in modern linguistics $[2 ; 9 ; 14 ; 16]$. However, the problem of interconnection and interaction of prosodic means in the texts of video presentations has not been studied profoundly, which determines the relevance of the chosen topic. The study of the functioning of prosodic means and the specifics of their interaction is reflected in the works of many Ukrainian and foreign researchers $[1 ; 3 ; 8 ; 10 ; 13 ; 17 ; 20 ; 21]$. At the same time, insufficient attention is paid to the study of prosodic organization of language units, which plays an important role in decoding the meaning of a video-verbal text.

The objective of this article is to define the main stages of carrying out a phonetic experimental research of prosodic means used for the pragmatic influence realization in English video presentations. It is achieved by fulfilling the following tasks:

(i) to outline the methods and material of the phonetic experimental research, (ii) to describe the research program and establish the succession of the experiment stages and their the main features, (iii) to systematize the prosodic parameters investigated within the framework of the auditory analysis, (iv) to study frequency, intensity and temporal characteristics at the acoustic level, (v) to reveal prosodic features used for the pragmatic influence realization in English video presentations.

Methods and material. To achieve the aim of the research and accomplish its tasks, an experimental phonetic study involves a number of general scientific methods, such as analysis and synthesis, induction and deduction, as well as linguistic methods of pragmatic and discourse analysis and special methods of phonetic analysis, i. e., auditory and acoustic analysis, method of linguistic interpretation of the obtained phonetic results and quantitative data processing to study prosodic means that take part in pragmatic influence realization. The research material comprises fragments of English video-verbal texts singled out from the Apple company videopresentations with a total duration of five hours.

Results and discussion. The purpose of experimentalphonetic research was to determine the specifics of the prosodic means used for the pragmatic influence realization in English video presentations. The program of experimentalphonetic research consisted of the following stages: 1) selection and recording of the experimental material on digital media; 2) auditory analysis of the experimental material by phoneticians; 3) acoustic analysis of prosodic means that take part in pragmatic influence realization in English video-verbal texts; 4) linguistic interpretation and generalization of the results of experimental phonetic research. The methodology of this experimental phonetic research is based on the research methods described in $[10 ; 12 ; 15 ; 16$; 17].

The aim of the first stage lies in the selection and recording of the experimental material, which was selected from open sources, namely from the Internet, and then it was recorded on digital media. The next task was to segment the recording due to the task of the study. Segmentation of the experimental material was performed using the program Sound Forge (version 4.5).

The aim of the second stage of a phonetic research lies 
in the experimental research and generalization of perceptual characteristics of intonation of the English-language video presentations. The research was carried out according to the classification of video-verbal texts on the basis of the program and methods developed by the author. Taking into account the emotional and pragmatic potential of the text, native English speakers and phoneticians assessed the features of the prosodic structure of the analyzed video presentations in relation to the functional purpose and the pragmatic direction of its structural elements. What is more, English-speaking auditors provided additional information on the peculiarities of the prosodic structure of video presentations.

During the implementation of the first stage of the auditory analysis native English speakers pointed out the close correlation of the prosodic features of a video presentation and its pragmatic potential.

Taking into consideration the varying interaction of prosodic and lexical and grammatical means, high emotional and pragmatic potential of the analyzed video presentations was confirmed by the results of the auditory analysis of the experimental material. An example of this is the beginning of video presentations, when speakers appear and the audience reacts quite emotionally (applause can turn into a standing ovation), which undoubtedly affects the speaker and the emotionality of his speech at its beginning. In particular, the pitch level of the beginning of the syntagm varies from medium high at the beginning of the meeting, when the speaker is pleasantly surprised by the audience's reaction to his appearance, to extra high and high, when the applause does not subside and the speaker cannot begin his speech. Accordingly, the range of syntagms varies from average at the beginning of the speech to wide and expanded in subsequent syntagms. The slow pace of speech can be heard, , which not only conveys the emotions of the speaker, but also the need to pause and wait until the applause subsides and the speaker can begin his speech: e.g., ${ }^{\wedge}$ Wow! $\cap$ 'Thank you! $\Rightarrow$ 'Thank you! $\Rightarrow$ 'Thank you! $\oplus$ 'Thank you! $\Rightarrow{ }^{\wedge}$ Wow! $\oplus^{\prime}$ Thank you! $\Rightarrow^{\wedge}$ Wow! $\oplus^{\wedge}$ Wow! $\oplus^{\prime}$ Thank you! $\oplus^{\wedge}$ Wow! $\oplus$ 'Thank you! $\Rightarrow$ 'Thank you! $\cap$ Prosodic characteristics of the beginning of the video presentation indicate that the speaker is experiencing a range of emotions: excitement, surprise, joy, admiration for the audience reaction to his appearance. At the same time, due to speaker's professional qualities, the filled pauses are not traced in their speech. As the result, the filler-words, which make the speech less convincing, distract from the main idea and negatively affect the audience's perception, are not used.

The terminal tones are of great importance as they indicate the high emotional and pragmatic potential of the analyzed texts. Due to the usage of terminal tones or their combination, the speaker can interest, intrigue, state the fact, establish contact with the audience and, thus, convince in the benefits of the product or technical innovation that the speaker presents in his speech.

The task of acoustic analysis was to verify the data obtained from the auditors. The use of modern computer programs allows to obtain relevant indicators for several parameters simultaneously, for example, the frequency, the localization of intensity (volume), the utterances and syntagms. The rate of frequency change was determined in the main or after/before the main tone group as well as the rate of frequency change for each utterance. This step allowed to determine the dynamics of updating keywords that are markers of the pragmatic influence realization in English videopresentations. Based on the methods in empirical prosody research $[11 ; 15 ; 18 ; 21]$, the video presentation frequency register scale is conditionally segmented into six main registers: high narrow $(\mathrm{HN})$, medium narrow $(\mathrm{MN})$, low narrow (LN), high wide (HW), medium wide (MW), full $(\mathrm{F})$. To register the frequency variation dynamics, the prosodic index in the terminal and pre / post-terminal part of the utterances was measured. The study of intensity characteristics at the acoustic level was carried out taking into account the following characteristics: the maximum intensity in the main tone group of the utterance, the minimum intensity, the difference between them, which is the range of intensity changes. The results of the research allow us to assert that the role of the intensity decreases on the terminal component, and the rate of frequency change becomes the main mean of the phrase.

Based on the study of the temporal component of the utterance, the absolute duration (duration of the sound of the utterance without pauses) was determined, the pause coefficients for each utterance were set and the exact duration of the pauses was set. Thus, the distribution of each type of pauses was statistically investigated.

Acoustic analysis was performed in accordance with conventional methods $[11 ; 19 ; 21]$, namely, determination of the studied parameters, division of audio files of speeches into utterances with the help of special software, analysis of the obtained phonetic segments with the help of software for sound signal processing, entering the obtained indicators into work protocols, conducting appropriate calculations using conventional formulas and linguistic interpretation of the obtained results.

Eight videos dedicated to the presentation of Apple's latest products with a total duration of about 10 hours were selected. Based on the task of experimental phonetic research, four videos were selected for auditory and acoustic analyses. The software Sound Forge (version 4.5) was used to convert the selected material to a $*$ wav audio file format. The use of information and communication technologies has made it possible to use a common array of experimental material in audio format, which is recognized by modern computer multimedia devices for further work. The quality of the recorded material did not change significantly. It should be noted that the use of videos caused some difficulties, as the recording had background noise, which distorted the prosodic parameters. The total amount of experimental material is 5 hours of recording. 110 utterances with a total duration of about 45 minutes were selected for acoustic analysis.

The electroacoustic analysis was performed using Speech Analyzer and Praat acoustic analysis programs. The Speech Analyzer program was mainly used, as it allows to investigate any utterance durations. The selection of material for acoustic analysis revealed some difficulties, as the video files soundtrack contained background noise, the audience's reaction to the speaker's remarks, etc. Therefore, 110 mostly distinct utterances were selected, which provided an opportunity to establish the main prosodic parameters. The selected utterances were not processed by software to avoid distortion of acoustic and prosodic parameters. In accordance with the objectives of our study 
and using the above mentioned software, the following prosodic features were set: total and absolute duration, pause rate, pause duration, number of intonation groups, tone range, and the speed of frequency.

Peculiarities of the actual division of phonation segments indicate the emotional attitude of the speaker to the subject of the speech. One of the objectives of the acoustic analysis was to define the average number of intonation groups in utterances, which was determined by the oscillogram research during acoustic analysis and compared to the data of auditory analysis. Determining the arithmetic mean for intonation groups in utterance, which is 3.15 , we indicate that the number of syntagms does not exceed 3-4 intonation groups per utterance in case of emotionally neutral speech. However, the utterances consisting of one intonation group and characterized by non-pause actualization were not considered according to the emotional criteria. The utterances containing two and more syntagms which exceeded the average number of syntagms, were analyzed due to intensifiers that would indicate such a division. In addition, the speed of frequency, the range of tone, and the pause ratio are reliable markers of the presence of the emothe above parameters are actualized in a complex interaction, and one of them is dominant. Therefore, we paid attention to the utterances, which were characterized by significant fluctuations in the speed of frequency, frequency range, and the number of intonation groups.

So, it can be argued that the material selected for the acoustic and auditory analysis is fully compliant with the technical standards of audio recording and it has not been processed by special programs for sound processing. The used hardware and software made it possible to obtain reliable data on prosodic parameters. The number of selected speeches and the total number of utterances is sufficient for acoustic and auditory analysis in accordance with generally tional speaker's attitude to the subject. We assume that all

accepted methods, and the data obtained are statistically significant. The acoustic analysis results confirmed the correlation with the data of experimental material auditory analysis and certify the following prosodic model: the range of tonal change decreases against the speed of frequency direction with the corresponding adjustment of pause factor. At the same time, there is a correlation between the frequency range and the speed of frequency depending on the pragmatic goal. Final investigation phase involves linguistic interpretation of the data obtained experimentally, that is their logical analysis, generalization, forecasting and conclusions.

Conclusions. Thus, the research develops a program and methodology for experimental phonetic study which involves linguistic description methods, the use of auditory and acoustic analysis, quantitative data processing to study prosodic means that take part in pragmatic influence realization in English video-verbal text. Therefore, the results of the auditory analysis prove that every component of intonation (speech melody, loudness, tempo, pausation, rhythm and timbre) contribute to better comprehension of information and pragmatic influence on the audience. Such prosodic parameters as localization of the logical stress on the key phrases, variability of terminal tones, in particular regular recurrence of falling, rising and compound fallingrising and rising-falling tones, slow and moderate tempo, interchange of short and long pauses are the most optimal for pragmatic influence realization and help to draw and maintain listeners' attention during the videopresentation. Linguistic interpretation of the results of experimental phonetic research proves that the data obtained during the acoustic analysis with the help of digital tools of speech analysis correlate closely with the results of the auditory analysis, and make it possible to use the results of the investigation in linguistic theory and practice.

\section{ЛІТЕРАТУРА}

1. Вербич, Н. С. (2011). Інтонація переконування в публічному мовленні: монографія. Луцьк: Терен. 208 с.

2. Завадська, О. В. (2016). Феномен креолізованого тексту: актуальна проблема сучасних лінгвістичних досліджень. Лінгвістичні дослідження: Зб. наук. праць ХНПУ ім. Г.С. Сковороди. Вип. 4, с. 163-169.

3. Калита, А. А. (2016). Энергетика речи: Монография. Киев: Кафедра. 292 с.

4. Лильо, Г. (2013) Вербальне vs. візуальне в перцепції креолізованих інтернет-текстів (на матеріалі інтернет-видання «Українська правда»). Вісник Львівського університету. Серія журналістика. Випуск 37, с. 412-418.

5. Нагорна О.О. (2015). Синкретизм вербальних і невербальних засобів у тексті ситуативної комедії (на прикладі комедійного серіалу “Тhe Mindy Project" /“Проект Мінді”) Науковий вісник кафедри Юнеско КНЛУ. Серія Філологія. Педагогіка. Психологія. Випуск 30, с.103-106.

6. Пойманова О.В. (1997). Семантическое пространство видеовербального текста: автореф. дис. ...канд. филол. наук: 10.02.19. M., $21 \mathrm{c}$.

7. Сорокин, Ю. А., Тарасов, Е. Ф. (1990). Креолизованные тексты и их коммуникативная функция. Оптимизация речевого воздействия. М.: Наука, 180-195.

8. Тараненко, Л. І. (2014). Актуалізація англійських прозових фольклорних текстів малої форми: Монографія. Київ: Кафедра. 288 с.

9. Чемеркін Г. (2008). Елементи техно у креолізованому художньому тексті. Мовознавство. № 4-5. С. 65-71.
10. Gussenhoven, C. (2006). Experimental Approaches to Establishing Discreteness of Intonational Contrasts. Methods in Empirical Prosody Research / edited by Stefan Sudhoff ... [et al] (2006). Berlin: Waltter de Gruyter, p. 321-324.

11. Hagiwara, R. (2009). How Do I Read a Spectrogram? Winnipeg: University of Manitoba. Available at https://home.cc.umanitoba.ca/ robh/howto.html

12. Phakiti, A., De Costa, P., Plonsky, L., \& Starfield, S. (Eds). (2018). The Palgrave Handbook of Applied Linguistics Research Methodology. London: Palgrave Macmillan.

13. Kozub, L. (2019). The Role of Prosodic Means in Realizing the Pragmatic Effect. International journal of philology. Kyiv: NUBIP, Vol. 10 (2), p. 45-50.

14. Kress, G.R., van Leeuwen, T. (2002). Multimodal Discourse: the modes and media of contemporary communication. London: Edward Arnold, $152 \mathrm{p}$.

15. Methods in Empirical Prosody Research / edited by Stefan Sudhoff ... [et al]. (2006). Berlin, N/Y.: Waltter de Gruyter, $392 \mathrm{p}$.

16. Norris, S. (2019). Systematically working with multimodal data: research methods in multimodal discourse analysis. New York: John Wiley \& Sons, 2019. 265 p.

17. Rietveld, T. \& Chen A. (2006). How to Obtain and Process Perceptual Judgements of Intonational Meaning. Methods in Empirical Prosody Research / edited by Stefan Sudhoff ... [et al] (2006). Berlin: Waltter de Gruyter, p. 283-320.

18. Rodero, E., Potter, R. F., Prieto, P. (2017). Pitch Range Vari- 
ations Improve Cognitive Processing of Audio Messages. Human Communication Research, 43, p. 397-413.

19. Thomas, E. R. (2001). An Acoustic Analysis of Vowel Variation in New World English. Durham: Duke University Press.

20. Valigura, O. (2017). Bilinguals and Linguistics of Creativity: the Case of Ukrainians Speaking English. Language - literature - the arts: a cognitive-semiotic interface. Chrzanowska-
Kluszewska, E., Vorobyova, O. (eds.). Frankfurt am Main; Bern: Peter Lang, Vol. 14, p. 261-277.

21. Valigura, O., Kozub, L., Sieriakova, I. (2020). Computer Technologies in Acoustic Analysis of English Television Advertising Discourse. Arab World English Journal (AWEJ), Special Issue on CALL. Number 6. July 2020, p. 38-48.

\section{REFERENCES}

1. Verbych, N. (2011). Intonation of Persuasion in Public Speech. Lutsk: Teren, $208 \mathrm{p}$.

2. Zavadska O. V. (2016). The Phenomenon of Creolized Text: Topical Issues of Modern Linguistic Investigations: Bulletin of the Skovoroda Kharkiv Pedagogical University. Issue 4, p. 163-169.

3. Kalita, A.A. (2016). Energetics of Speech: Monograph. Kiev: Kafedra, 292 p.

4. Lylo, H. (2013) Verbal vs. Visual in Perception of Creolized Internet Text в перцепції креолізованих інтернет-текстів (on material of internet media "Українська правда") на матеріалі інтернет-видання «Українська правда»). Messenger of Ivan Franko National University of Lviv Вісник Львівського університету. Series: Jounalistics. Issue 37, p. 412-418.

5. Nahorna O.O. (2015). Syncretism of linguistic and non-linguistic means in the text of the situational comedy (based on the sitcom "The Mindy Project"). Scientific messenger of the UNESCO department of Kyiv National Linguistic University. Philology. Pedagogy. Psychology. Kyiv: Kyiv National Linguistic University, 2019. No. 30. p. 103-106.

6. Poimanova O.V. (1997). Semantic Space of Video-verbal Text: Synopsis for thesis for the candidate degree in philology. Specialty: 10.02.19. M., $21 \mathrm{p}$.

7. Sorokin., Yu., Tarasov, Ye. (1990). Creolized Texts and Their Communicative Function. Optimization of Speech Influence. M.: Nauka, p.180-195.

8. Taranenko, L. (2014). Actualization of English Small Form Folk Texts: Monograph. Kyiv: Kafedra, 288 p.

9. Chemerkin G. (2008). Techno Elements in a Creolized Literary Text. Language Studies, № 4-5, p. 65-71. 